\title{
An Analysis of
}

\section{Hotel-Impact Studies}

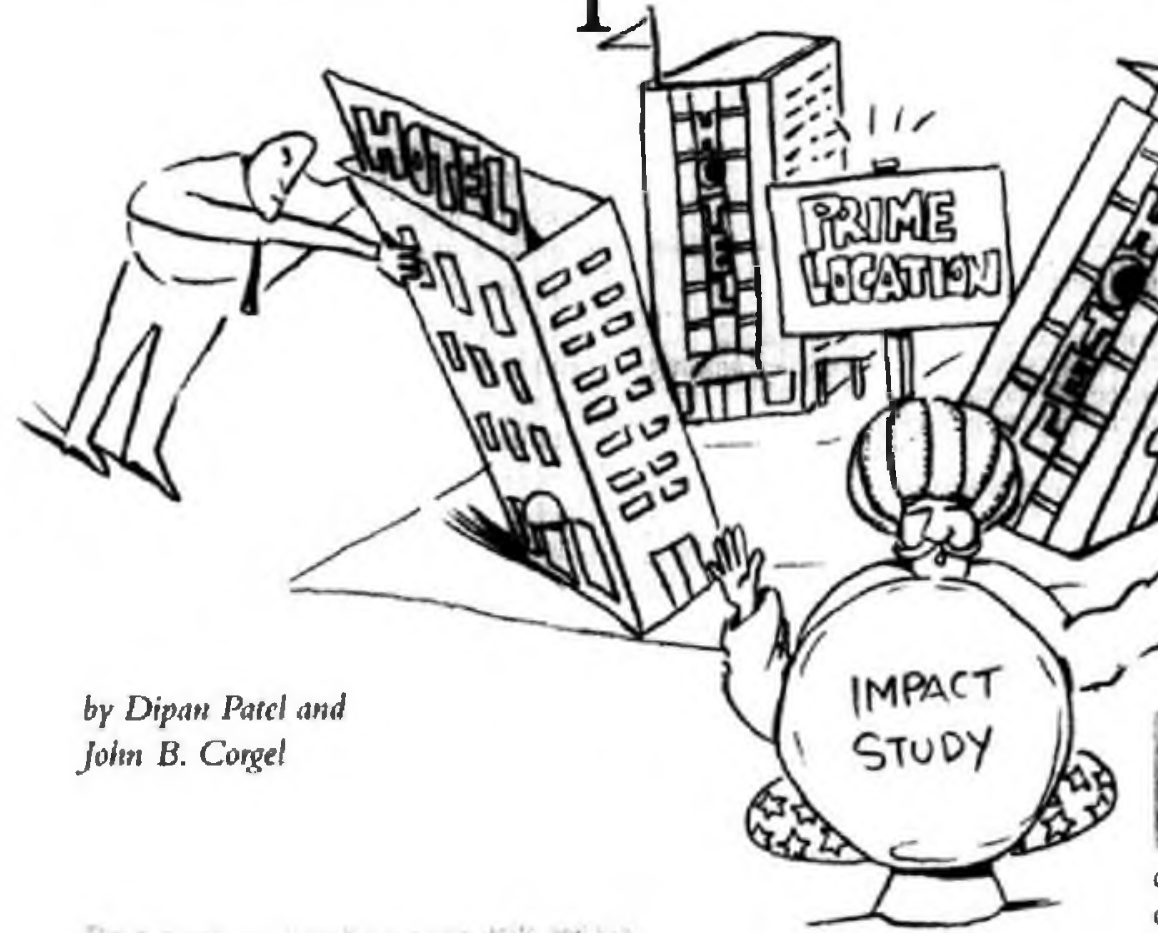

ranchising has allowed lodging companies to increase the number of units in their systems well beyond the increases possible through development of company-owned units alone. Because of franchising, companies can rapidly expand brand awareness, consumers have better access to hospitality products and services, and entrepreneurs are af-

Formerly with Days Inn of America and Hospitality Franchise Sysiens, Dipan Patel, who holds a Master of Professional Studies degree frows Cornell University, is a real-estate analyst with Hotel Parmers, a hotel-brokerage firm. John B. Corgel, Ph.D., is an associale professor as the Cornell University School of Hotel Administration.

e 1995, Connell Universily 


\section{Exhibit 1}

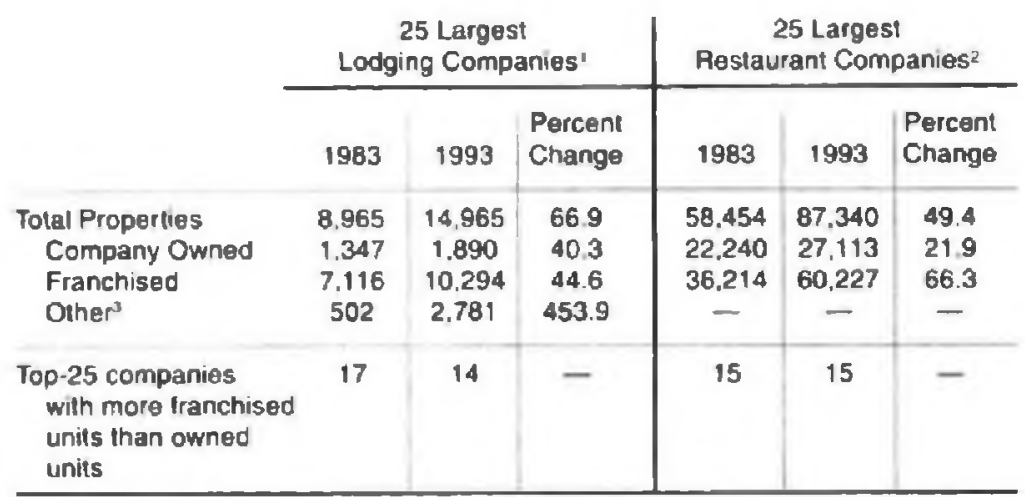

Loaging Hospitally August 1984. pp 60-61: and Lodging Hospitallty. August 1994, pp, 52-54

* The 1984 Technomic Top 100 The Larges! U S. Chain Restaurant Companies (Chicago: Technomic. Inc. 1984). and The 1994 Technomic Top 100: The Larges! US Chain Pestaurant Companies" (Chicago: Technomic, Inc., 1994)

Includes management contracts and reservation-system contracts.

forded opportuntics to own and operate nationally recognized busine'sses. The information provided in Exhibit I shows how the growth of many firms in the hespiciliry industry during the last ten years has resulted from expansion of their iranchise systems.'

Expansion via franchising, however, creates conflict between franchisors and franchisees when that expansion encroaches on existing properties. Franchise contraces contain detailed provisions governing the relationship herween franchisors and franchisecs for the conduct of business at specific locations, but usually do not restrict the

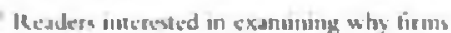

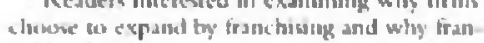

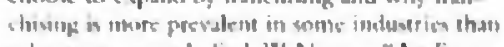
us hess may cusmule Seth W. Nartan. ${ }^{-A}$ An Em-

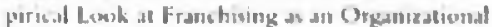

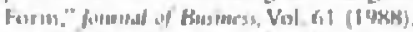

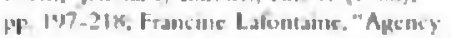
Theory and Franchusalg: Sonde Empurical Kre

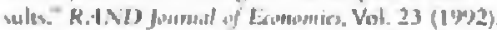

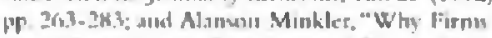

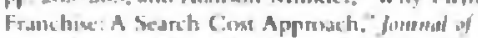

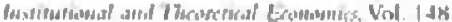

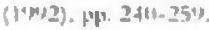

franchisors' ability to expand the franchise systems withils a territory. Masy franchisecs believe they have lost business as a result of cannibatization from new unirs in the same chain. a phenousuenon referred to as "impact" in the lodging and foodservice industries. Disputes between frauchiseces and franchisors over territorial encroachnent have elicited responses from sonnc state legislatures, which enacted laws to protect franchisecs from encroachment. and from the franchisors themselves. many of whom are instituting pollcies for managing the impact of system expantion on existing franchised units.?

An integral part of hospicalitycompany impact policies is the requirement that impace studies be performed whenever proposed units may siphon business from existing

\footnotetext{
An excelleni neview of state statutes and common law oul sncroachruent is tound in: Rupers M. Harkoff and W. Michael Garner.

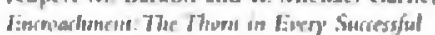
Fwarhisar's Side (Dallas. Texas: Anuerkan Bar Asmociacion Foruni on Franchustup. 1993)
}

units. Most franchise companies use independent consultants to perform these studies (e.g., Choice International), while others somerimes produce studies internally (e.g. Holiday Inn Worldwide) ${ }^{3}$

Critique. As the hospitality industry's evaluation of franchise impact begins to approach nuaturity, we believe the time is appropriate for a critique of the process and methodology of impact assessment. As part of our review, we collected and examined 24 externally and internally prepared impact studies for new lodging properties or conversions of existing units, grading the studies for their methodology and content. We found substantial room for improvement in the way in which impact assessments are performed. Specifically, impact assessment appears to be reactive sather than proactive, and impactstudy methodology, in its current forn, relies too much on subjective interpretations.

After reviewing impact policies and procedures and reporting on the findings of our evaluation of impact studies, we recommend an alternative conceptua] and empirical approach to irnpact assessment that is proactive and should be more objective.

\section{Evalualing Impact}

We developed the flow charr in Exhibit 2 us show the typical inzpact-evaluation process followed by hotel-franchise companies. The process begins when a prospective franchisec makes an application. The four key decision points in the process are the impact-policy test, objection letters, internal resolution, and the impact study itself.

\footnotetext{
- We provide sonie details sbout impacr studies in subsequent sections of this article. Fot a detaicd procedural discussion, see the article try Ruchel J. Riximky." A Ciritical Analyss of Hotel-Impact lswes" (pp. 18-26 of this Connell Quariedy).
} 
All franchisees in the area specified by the company's policy who may be affected by the proposed unit receive a notification letter. The responsibility for objecting to the application falls completely on the affected franchisees. Most franchisors require submission of a formal objection form that contains property-level and general market data such as occupancy, competirion, and average daily rate. If the existing franchisees choose not to object, then the impact issue is closed and the application continues to be processed.

If an existing franchisee sends a formal objection letter, however, potential impact becomes an issuc. The franchisor reviews. any objection letters and negotiates with the affected franchisees in an effort to resolve issues raised in the letter. In some instances, franchisors are willing to share the cost of allowing the new unit to be part of the system (e.g., by reducing royalty fees for a specified period of rime). If, however, the parties fail to resolve the issue, they commission an impact study.

After the completion of the study, the franchisor and franchisees review the results. If all parties agree with the findings of the study, impact ceases to be a point of contention. If an agreement is not reached, however. the issue may be raken to nonbinding arbitration. Notwithstanding this procedure, the final decision about the creation of new franchise units lies with the franchisor.

\section{Lodging Companies' Impact Policies}

Viewed broadly, the impact policies of major franchisors are the guidelines for franchisesystem growth. Protection

\section{Exhibit 2}

\section{Tynical impard-analysis orocess}

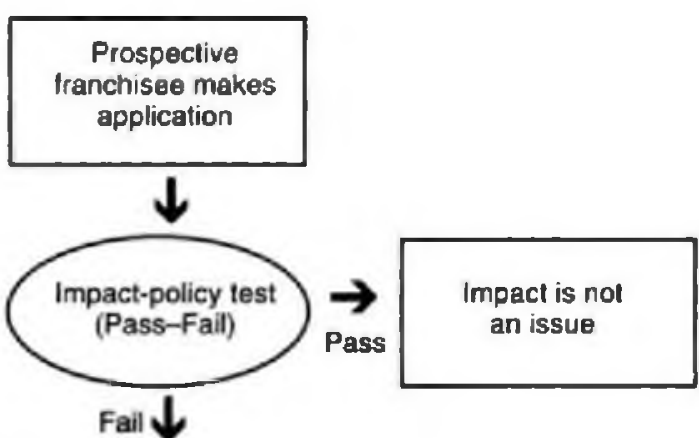

Impact may be an issue. Notification letters mailed.

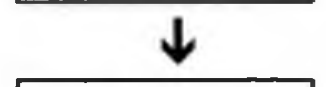

\section{Existing-franchisee} response period

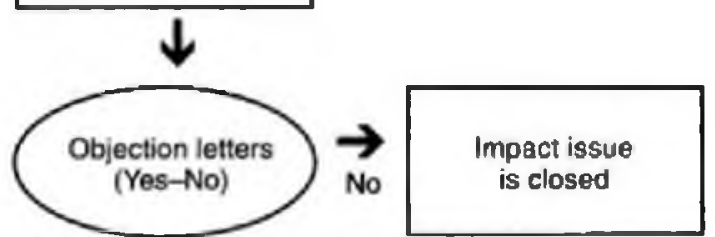

Yas

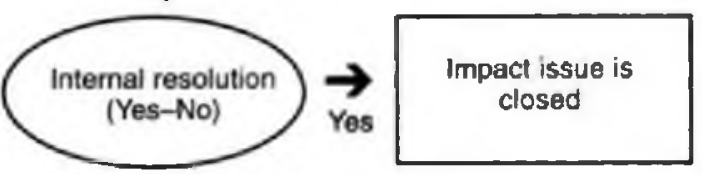

No $\downarrow$

Impact study

Issue goes to arbitration

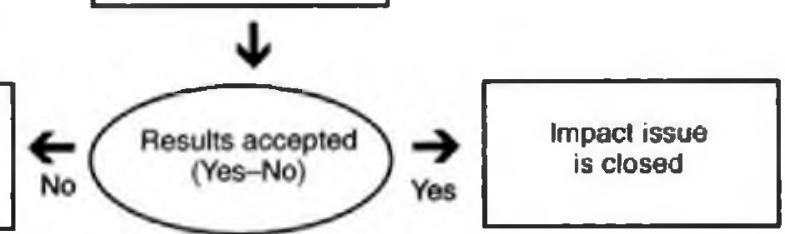


Exthibli 3

Lodging franchisors' impact policies

\begin{tabular}{|c|c|c|c|c|c|c|}
\hline Franchleor & Brands & $\begin{array}{l}\text { Pollcy } \\
\text { Objective }\end{array}$ & $\begin{array}{c}\text { Nollfication } \\
\text { Area }\end{array}$ & $\begin{array}{l}\text { Reopones } \\
\text { Period }\end{array}$ & $\begin{array}{l}\text { Objection-Letter } \\
\text { Requirement: }\end{array}$ & $\begin{array}{l}\text { Impect } \\
\text { Threshold }\end{array}$ \\
\hline $\begin{array}{l}\text { Holiday Inn } \\
\text { Worldwide }\end{array}$ & $\begin{array}{l}\text { Holiday Inn. } \\
\text { Crowne Plaza. } \\
\text { Express, } \\
\text { SunSpree }\end{array}$ & None staled & $\begin{array}{c}3 \text { nearesl } \\
\text { properties. } \\
\text { any HIW brand }\end{array}$ & 14 days & $\begin{array}{c}\text { Written comments. } \\
\text { Holiday Inn } \\
\text { property-survey form }\end{array}$ & None sel \\
\hline $\begin{array}{l}\text { Hospitality } \\
\text { Franchise } \\
\text { Systems }\end{array}$ & $\begin{array}{l}\text { Days Inn, } \\
\text { Howard Johnson, } \\
\text { Park Inns. } \\
\text { Pamada. } \\
\text { Super } 8\end{array}$ & $\begin{array}{l}\text { To allow expansion } \\
\text { of the system } \\
\text { without substantial } \\
\text { adverse impact on } \\
\text { existing properties }\end{array}$ & $\begin{array}{l}\text { Same brands in } \\
\text { the greater of a } \\
15 \text {-mile radius or } \\
3 \text { closesi } \\
\text { properties }\end{array}$ & 15 days & $\begin{array}{l}\text { Writen comments } \\
\text { based on impact- } \\
\text { response-guide } \\
\text { requirements }\end{array}$ & $\begin{array}{l}3 \text { cocupancy } \\
\text { points in any of } \\
\text { first } 3 \text { years } \\
\text { ( } 2 \text { points for } \\
\text { new construction) }\end{array}$ \\
\hline $\begin{array}{l}\text { Choice } \\
\text { International }\end{array}$ & $\begin{array}{c}\text { Clarion, } \\
\text { Comion Inn. } \\
\text { Econo Lodge. } \\
\text { Friendship Inn. } \\
\text { Quality Inn. } \\
\text { Rodeway Inn. } \\
\text { Sleep Inn }\end{array}$ & $\begin{array}{l}\text { To ensure minimal } \\
\text { incremental impact } \\
\text { Irom addition of } \\
\text { properties } \\
10 \text { Choice system }\end{array}$ & $\begin{array}{l}\text { Same brand: } \\
15 \text { mi.; } \\
\text { Same lier: } 8 \mathrm{mi} \text {;: } \\
\text { All brands: } 5 \mathrm{mi} \text {.; } \\
\text { Minimum } \\
3 \text { propenties } \\
\text { regardless } \\
\text { of brand }\end{array}$ & 10 days & $\begin{array}{l}\text { Management- } \\
\text { comminee letter of } \\
\text { Iomal objection } \\
\text { (required to trigger } \\
\text { impact sludy) }\end{array}$ & $\begin{array}{l}\text { Average of } 3 \\
\text { or more occupancy } \\
\text { points during } \\
\text { first } 5 \text { years. or } \\
\text { incremental impact } \\
\text { of } 5 \text { or more poin's } \\
\text { during any of } \\
\text { lirst } 5 \text { years }\end{array}$ \\
\hline Best Western & Best Westem & $\begin{array}{l}\text { To enable informed } \\
\text { decisions regard. } \\
\text { ing membership } \\
\text { development without } \\
\text { an impact on existing } \\
\text { members and } \\
\text { considering best } \\
\text { interests of association }\end{array}$ & $\begin{array}{c}10 \mathrm{mi} \text { in metro } \\
\text { areas } \\
\text { (over } 100,000 \text { ). } \\
25 \mathrm{mi} \text { in } \\
\text { rural areas }\end{array}$ & NA & $\begin{array}{l}\text { Complele property } \\
\text { and market } \\
\text { survey form }\end{array}$ & None set \\
\hline
\end{tabular}

against overly aggressive groweth of the franchise system is often a point of negotiation between the parties. but is not standard in most conrracts. Only a few lodging companies such as Super 8, Park Inns, and Knights Inns, offer protection clauses in franchise contracts.

The impact policies of most major lodging-franchise companies including Choice International. Hospitality Franchise Systems (HFS), Holiday Inn, and Best Western are similar to each other. These policies, summarized in Exhibit 3. define the notitication urea, the period for raising objections, requirements for objection letters, and impact threshold, or the acceptable level of impact on existing units resulting from the new unit. Choice International and HFS, for instance. use a threshold of the loss of three percentage points of occupancy to define adverse impact.

The thresholds appear to be arbitrary. If an impact study shows less than a 3-point drop in occupancy for affected properties in the first year, the proposed franchise is deemed acceptable. A critical problem with using this hurdle-rate approach is that it shifts the burden of making a decision from the franchisor to the consultant. Moreover, the 3-point benchmark is an arbitrary number applied by franchisors. Impact-policy documents offer no evidence to support the use of a 3-point threshold level."

The size of the notification area also seems arbitrary. Typically, existing units within a 15 -nule radius of the new unit are notified of the franchise application. While Best Western defines the notification area

\footnotetext{
"Another problem with using a threshold selated only to occupancy is that the impact on room rate is ignored. In response to this issue, some loding fronchivon now specify a threshold of sross roons income or revenues pet avalable room (REVPAR) imsead of accupancy fate in company

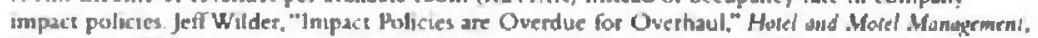
October 3, 1944, p. 13. rccummends that the protit-and-loss statenents of affected franchisers be examined as part of impact asesument. W/ldef's fecommendation takes into consideration chankes in expenses.
} 


\section{Exhibit 4}

\section{Dutline of typical impact s!udy}

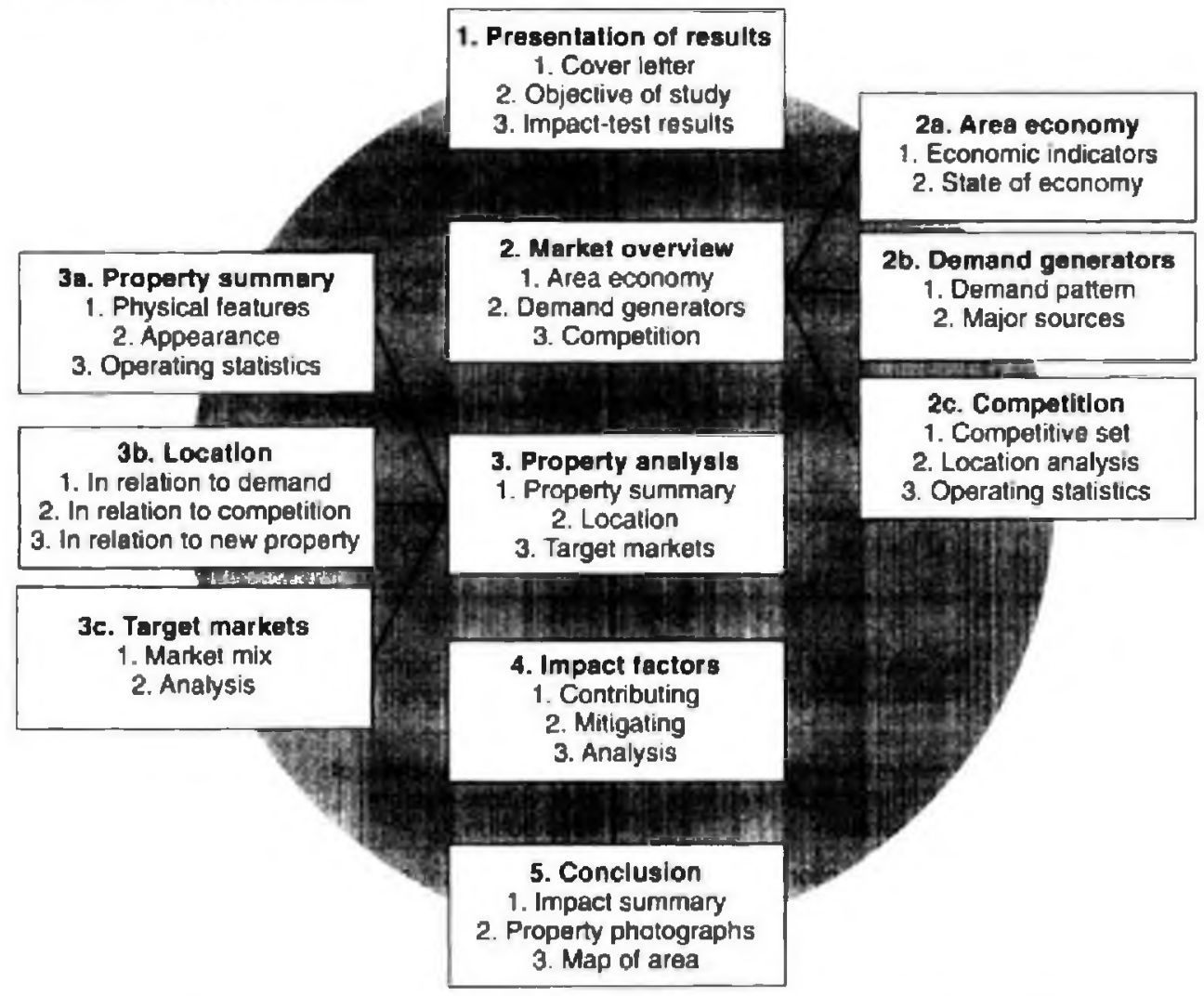

in accordance with market characteristics, the policies of other lodging franchisors are silent on the relationship between market characteristics and the notification area. ${ }^{3}$

\section{Impact Studies}

An impact study forecasts the potential financial changes for existing units when a urat of the same brand or a similar brand with a common affiliation is added nearby. The fi- nancial analysis is limited to the incremental impact on overall occupancy, average rate, or revenue and does not take into account expenses or proficability: The analyst first calculates the base impact, which is the financial loss or gain of existing units in a market resulting when any addicional lodging property (wsually a competitor) opens within the trading area. Then the analyst must estimate the incremental impact that

\footnotetext{
"Consider two application seceived by a franchisor. The first applicatson is for a fraschese at an interstatc - highway exit; and the recond application is for a franchise at a suburban location. If both applications are just over 15 miles from the nearest existing franchise, they pass the impact-polacy tes Althoukh both applications are analyzed using the wme impact policy their impasts may be quite different. The suburban location may be a distinct markes. The highway locanon, however, cuuld cause serious impact so existing franchises because interstate travelers are somewhat induferent to hotels that are around 15 miles apart on an interstate. Thereforc, although both applications are accepted by the franchisor the impact of the interstate locasion on exisung franchisors is potentialty greater because of the endemic market characteristics.
}

results from the new unit's having the same or an affiliated brand. a common reservation systcm, and related marketing programs."

The study muse discuss factors that curatribute to or mitigate impact. Some such factors are the locations, target-market segments, and physical atcributes of the unics. If. for instance, the proposed unit is not uear the existing property, then location is a mitigating factor. Although there is no set format guidelines, we found the formats of most studies to be similar, as shown in Exhibit 4 .

"This process a described more fully in the accompanying article by Rachel J. Roginsky. "A Crietcal Analysis of Hotel-Impact Issues" (pp. 18-2h of this Comell Quarierly). 


\section{Exhibit 5}

\begin{tabular}{|c|c|c|c|}
\hline Area of study & (poOr) & (average) & (good) \\
\hline \multicolumn{4}{|l|}{ Markel bsckground } \\
\hline $\begin{array}{l}\text { Markel overview } \\
\text { Supply and } \\
\text { competition }\end{array}$ & $\begin{array}{l}\text { Unclear definition of } \\
\text { compelitive sel and basis for } \\
\text { supply projeclions }\end{array}$ & $\begin{array}{l}\text { Competition well-defined but } \\
\text { with some inconsistencies; } \\
\text { supply well-described but } \\
\text { without statistical analysis }\end{array}$ & $\begin{array}{l}\text { Use of statistical lools and } \\
\text { market research in delining } \\
\text { competitive set and } \\
\text { explaining supply }\end{array}$ \\
\hline Demand analysis & $\begin{array}{l}\text { Unclear descriplion } \\
\text { and analysis ol demand } \\
\text { generators }\end{array}$ & $\begin{array}{l}\text { Demand generators well- } \\
\text { described but lack evidence } \\
\text { of analysis }\end{array}$ & $\begin{array}{l}\text { Evidence of demand. } \\
\text { generator analysis with } \\
\text { regression model to projecl } \\
\text { demand }\end{array}$ \\
\hline Location analysis & Poor description of location & $\begin{array}{l}\text { Location well-described but } \\
\text { lacks analysis }\end{array}$ & $\begin{array}{l}\text { Good analysis of trattic flow } \\
\text { and relationship to demand } \\
\text { generators }\end{array}$ \\
\hline Property analysis & $\begin{array}{l}\text { Poor description of lacilities } \\
\text { and fealures }\end{array}$ & $\begin{array}{l}\text { Good description but no } \\
\text { quantitative analysis }\end{array}$ & $\begin{array}{l}\text { Ouantitative comparison of } \\
\text { properties, good analysis of } \\
\text { impact due to facilities }\end{array}$ \\
\hline \multicolumn{4}{|l|}{ Market segment } \\
\hline $\begin{array}{l}\text { Brand marketing } \\
\text { program }\end{array}$ & $\begin{array}{l}\text { No mention of brand's } \\
\text { marketing program }\end{array}$ & $\begin{array}{l}\text { Objectives of brand's } \\
\text { markeling program described }\end{array}$ & $\begin{array}{l}\text { Analysis of program's impact } \\
\text { on target market segments }\end{array}$ \\
\hline $\begin{array}{l}\text { Reservations } \\
\text { system }\end{array}$ & $\begin{array}{l}\text { Reservations-system } \\
\text { contribution not taken into } \\
\text { consideration }\end{array}$ & $\begin{array}{l}\text { Reasonable analysis of } \\
\text { reservations-5ystem } \\
\text { contribution }\end{array}$ & $\begin{array}{l}\text { Market-segment analysis } \\
\text { based on market research }\end{array}$ \\
\hline $\begin{array}{l}\text { Property-segment } \\
\text { analysis }\end{array}$ & $\begin{array}{l}\text { Poor description and analysis } \\
\text { of market segments }\end{array}$ & $\begin{array}{l}\text { General market-segment } \\
\text { analysis with broad } \\
\text { description }\end{array}$ & $\begin{array}{l}\text { Reservations-system analysis } \\
\text { includes bookings, denials, } \\
\text { and month-by-month analysis } \\
\text { of contribution }\end{array}$ \\
\hline Impacl summary & $\begin{array}{l}\text { Poor description of impact } \\
\text { lactors }\end{array}$ & $\begin{array}{l}\text { Impacl lactors well-described } \\
\text { but without quantitative } \\
\text { analysis }\end{array}$ & $\begin{array}{l}\text { Quantitalive analysis of each } \\
\text { factor's impact }\end{array}$ \\
\hline Reliabillty of data & Poor & Average & $\begin{array}{l}\text { Good (Smith Travel, } \\
\text { registration cards) }\end{array}$ \\
\hline $\begin{array}{l}\text { Use of economic } \\
\text { indleators }\end{array}$ & Poor & Average & Good \\
\hline Objective of study & Poorly detined & Average & Well-defined \\
\hline
\end{tabular}

\section{Evaluation of Impact Studies}

Using the standards shown in Exhibit 5. we evaluated a simple of recent studies. In our estimation, tht standards are based on principles of logic and sound professional pratrice. The studies were graded in the eight contert areas and earned ai) overall grode for meeting their objectives. The minimum grad: assigned to each section or subsec- tion that did a poor job of meeting its objective was one poitht. For example. a study that included only a sketchy description of the prosposed unit's location and the location of potentially affected units would receive one point for that section. The maximum grade per section or subsection was five. given to studies that did an excellent job in these areas. We gave credit for 


\section{Exhibit 6}

Imancl-study scares

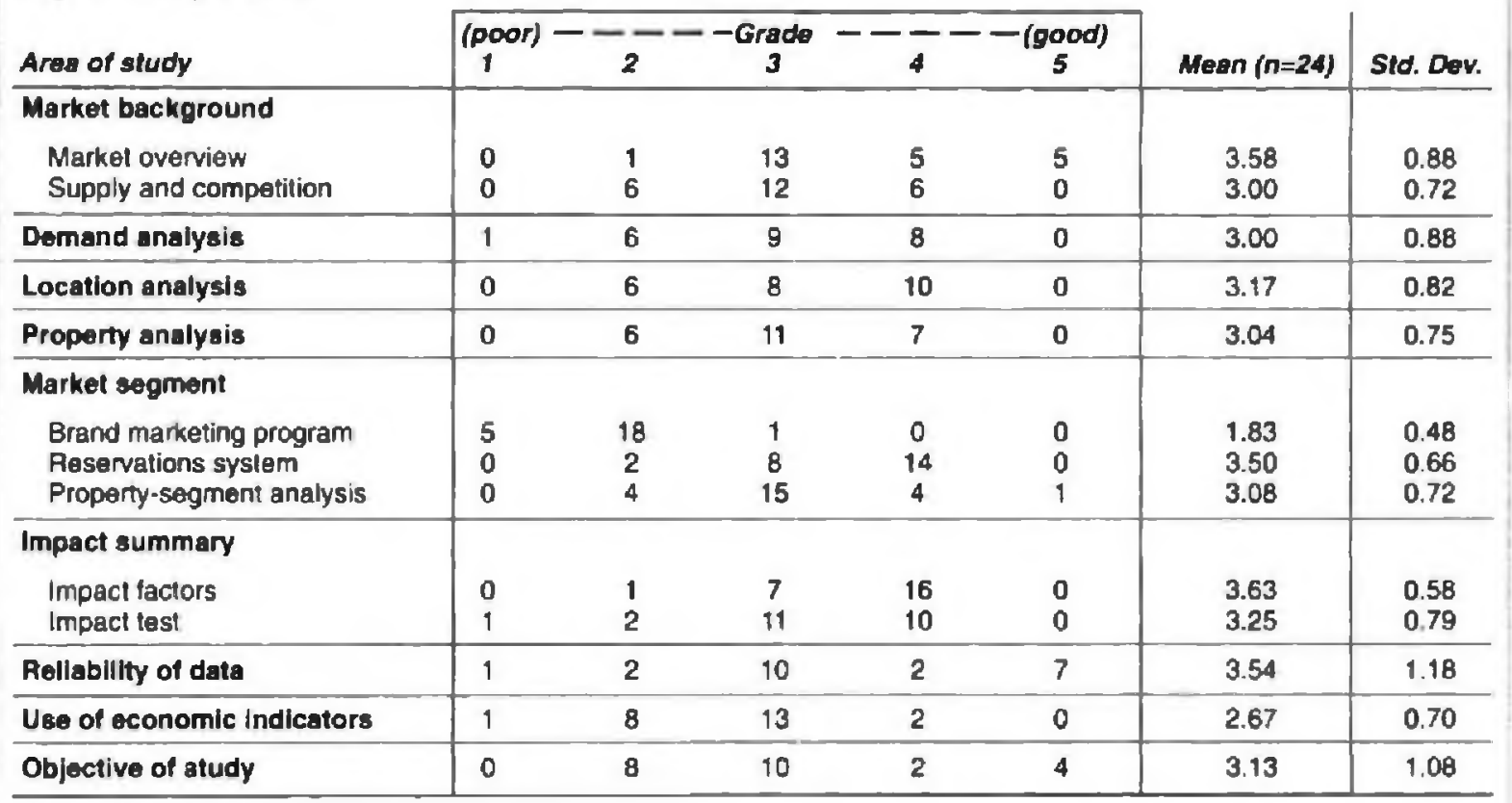

Note: The table shows the number of impact studies achieving the grade at the top of the column for each of the topics listed at let. So. for example. 13 studies earned a grade of 3 for their markel overview.

The mean shows the average score for all the studies on each lopic. Scoring is according to the authors' scheme shown in Exhibil 5 and explained in the lext

quantitative analysis to studies that applied statistical tools and provided evidence of market research. Many studies earned grades in the threeto-four range because they included adequate description. but lacked quantitative analysis or other supporting data.

Data collection. We gathered a sample of impact studies from consultants and franchisors. A chief selection criterion was avilability. We make, therefore, no claim of random selection, comprehensive industry representation, or generalizabiliry. Yet the 24 studies that compose the sample were performed by 12 different consultants at various consulting practices. The studies are from three different hotel companies representing 12 brands. In addition. the hotels range in size from 40 to
250 rooms and are located in markets throughout the United States.

The studies were conducted between January 1991 and December 1993. Due to their confidential nature, we do not disclose names or locarions.

\section{Results}

The results of the analysis presented in Exhibit 6 are organized by seccion in accordance with the rypical impact-study format. Mean standard deviations are given for results in each caregory. We comment below on our ratings for each section.

Market background. The market-background scction analyzes the overall condition of the market, the comperition, and demand generators. Most studies did a good job of describing the market conditions, but a poor job of analyzing those conditions.

Specifically, we identified problems in the analysis of supply trends and in the definition of comperitive sets. The studies betray little evidence of interviews with local developers, chambers of commerce, and hotel owners to support supplygrowth forecasts. With regard to determining the competitive set, many studies rely entirely on interviews with the management of the affected properties and the analyst's personal judgment. Because impact is usually estimated down to one percentage point, misallocation of the competition may result in serious errors. For example, one study included a 2,000-room Hilton properry as part of the comperitive set for economy hotels. 
Although management interviews and industry experience are common ways of determining conzpetitive sets, personal bias remains an issuc. Alternarively, the application of consunterswitching data, which shows consumers" lodgingchoice patterns, has been shown to be an unbiased approach to defining competitive sets.? Although it may be unreasonable to assume that consultants will develop consumerswitching databases. franchisors have the resources to develop competitive-set models.

Studies that provided a demand analysis - offering potentially valuable data-focused on the overall market. Such a broad approach did not address the individual property's competitive position as effectively as would an analysis targeted on the growth rate of the market segments soughe by the hote! in question. Understanding growth rates by segment is critical because of the difference in properties market mix. A good starting poine is to conduct demand-generator interviews to gauge the market's demand stability and furure potential. Some studies provided evidence of such interviews, but this practice does not appear to be standard in the industry or among consultants.

Another problem we discovered with the studies" demand analysis is the practice of aggregating demand

'See: Michaed S. Morgas and Chekitan S. Dev, "Dcfining Cumpetitive Sets of Hotel 13rands Through Analysis of Consumer 13 rand Swathing." Joumal of Haspisality E- Lersure N/arkerping. Vol. 22 (1994), pp. 57-4)1. over the entire year. Aggregation makes it difficult to portray the seasonality of businesses. Only a third of the studies showed a month-by-month analysis of demand. One study described the status of the overall demand in the area without providing any description or analysis of the demand generators.

Location analysis. The location analyses of the impact studies we reviewed were generally limited to a discussion of the relarive distance from demand generators to the existing and proposed propertics. Although most studies did an excellent job of describing the study area. relacive distances (e.g., actual driving times between sites) were not meneioned in all scudies. We also found no evidence of research on the consumer-reservation distance, which is the maximum distance consumers are willing to travel from their business, home, or other poine to reach a hotel. "The location analyses would be stronger if they showed driving distances and times on an area map with a depiction of a property's location relative to demand generators. Such an analysis would be further improved if franchisors were able to supply customer-survey data that indicate reservation distances.

Property analysis. An impact study's properry analysis is important because of the potential effects of a property's characteristics on consumer decisions. To evaluate features that influence consumer choices. studies ought to consider the key features involved in the decision. and then measure the importance of these features to consumers. Some key features include curb appeal, brand name. physical facilicies, and location. The studies we evaluated provided a comparative property

\footnotetext{
"Sec: W. Back. "Cihoice-Set Detinution in Patronage Modeling." Jownal of Resailing, Vol. (N) (1484), pp. 63-65
} 
analysis, but the aralyses are not quantitarive and the studies falled to list the properties' characteristics in terms of consumer priority.

Market-segment analysis. Although most studies offered information about market segnsentation, the analyses were limited to a small number of market segments and the information was based solely on interviews with management. Market-segmentation analysis is driven by an umderstanding of brand marketing programs, the brand's reservation system, and the specific segments served by the property.

Brand marketing. One of the weakest areas of the studies we examined, with over 90 percent of the studies scoring below what we judged should be a middling effort, is the review of the brand marketing program. A brand's strength is directly related to its masketing program. Thus, an analyst should requesc information about company marketing programs, including specific segments targeted by the brand's marketing dollars, and the brand's scgment share. Impacr studjes likewise should take those factors into account.

Reservations. In contrast, we foumd the reservations-system analysis to be one of the strongest points of the impact studies, with over 50 percent of the studies scoring better than our midpoint of three. Franchisors supply a considerable amount of data to consultants, typically including information about the monthly reservation volume. cancellations, and denials. The only shortcoming we saw in the studies was the lack of irend analysis of reservations data.

Impact analysis. The results of most studies ate presented in a cable showing the porential itspact on properties for a period of five years. The typical format includes a description of impact factors and an impact-summary test. Most studies list approximately eight factors that either contribute to or nitigate impact. Those factors include the physical differences of the properties. similar demand sources, proxinity; and reservation-system contribution. For example, a study in New Jersey mentioned reservationsystem priority as a factor that mitigates impact. But rather than provide an analysis based on research, the analyst simply assumed that impact was mitjgated simply because the proposed property would be listed in the system directory following the existing property. Although most studies adequately described impact factors, they lacked objective quantitative analysis of those factors.

The impact-summary test shows the impact on occupancy percentage or some other measure of financjal performance. The impact studies we reviewed took their greatest leap of faith at this point, particularly considering the highly subjective nature of transforming qualitative impace factors to quantitative results. Other leaps of faith occurred with the length of the projections, the use of aggregate numbers by year rather than a month-by-month analysis, and reliance on occupancy rather Reservations-system analyses were one of the strongest points of the impact studies we reviewed. The only shortcoming we saw in these seclions of the studies was the lack of trend analysis of reservations data. than other, morecomprehensive measures of financial performance.

Reliability of data. The sources of data for most impact studies are the management of the affected property (or properties) and the franchisot. The information from management may be tainted by self- 


\section{Exhibil 7}

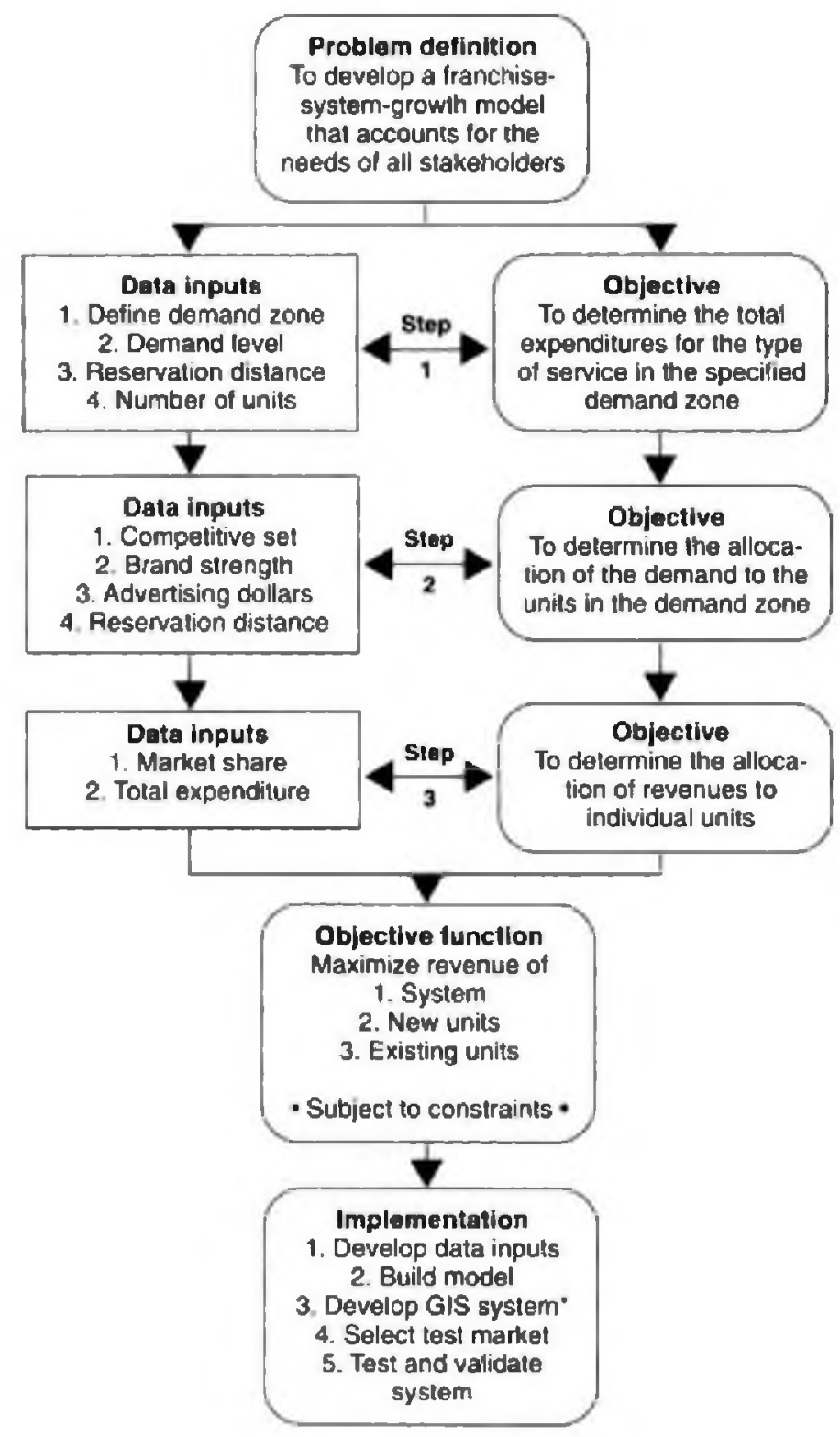

-For a discussion of GIS sysiems and applications, see: Christopher C. Mullet and Crist Inman. "The Geodemographics of Restaurant Development." Comell Hotel and Festaurant Administration Quarterly. Vol. 35. No. 3 (June 1994). pp 88-95: and Michael Shriber, Christopher C Muller, and Crisi Inman. "Population Growth and Reslaurant Success." Comell Horel and Restaurant Administration Quarterfy, Vol. 36. No. 3 (Wune 1995), pp 43-49-Ed interest, compromised by the lack of reliable records. and limited by concerns about disclosure.

Data from the franchisor and data companies, such as Smith Travel Research, are generally more reliable than data from local managers. Impact analysts have available to them such information as property occupancy. $A D R$, and reserva. tion volume. Studies performed by major consulting firms earned higher grades in this category than orhers because of dara supplied from in-house research. In addition. some studies effectively used hotel bed-tax records or lodgingtax records to estimate overall market revenues.

Use of economic indicators. The studies made poor use of general economic indicators. Although these indicators may not direcrly influence impact conclusions, they support intermediate suppositions about growth in supply and demand. Some relevant indicators that are generally available from local sources include offices-space use, employment growth, and employment mix.

Objective of study. The studies" statements of objectives varied widely. Some of the berter studies clearly specified their objectives. scope, and limiting assumptions. For instance, one of the effective studies explained the different possible outcomes in terms of an as-is scenario, a same-brand-conversion scenario, and a different-brandconversion scenario.

The need for substantial improvement in the methods used to analyze impact is apparent. Currently. Choice International, Holiday Inm, and HFS are evaluating the accuracy of past studies. In addition to the efforts of the franchisors, the International Socicty of Hospitalicy Consultants has conducted foruns that bring togecher industry leaders (i.e.. 
franchisors and (ranchisees) to discuss improving the impact-assessment process.

\section{Improving Impaci Assessment}

The quantum leap suggested by that cossultant may come from a modification of the underlying conceptual foundation of impact assessmest. Currently, impact policies are reactive. The franchisor receives an application for a new franchise unit and examines its potential impact on existing urits only after the local franchisees object. We suggest as alternative, proactive-policy concept implemented through the application of a franchise-system-growth model. Mulciple itcrations of such a model identify locations where incremental impact would be the most or least severe. Impact policjes emerging from franchisor growthmanagement plans would allow further evaluation of applications only if they are consistent with the growth plan. Those plans would be developed cooperatively by the franchisor and franchisees.

Such an approach may sound unrealistic in today's environment, but the framework exists to build londging-franchise-growth models. One of the most promising avenues is an adaptation of the FRANSYS model.

Fransys. The fransys model developed by Ghosh and Craig is a promising, but as-yet-unexplored foundation upon which to develop a franchise-system-growth model for the hospitalicy industry." The model divides a market into demand zones and then allocates a share of market revenues to individual units. As the number of same-brand units increases, the model applies a multiplier (alpha) to increase total expenditures in a demand zone-but at a decreasing

\footnotetext{
"AFyjt Chosh and Samuel Craig, "FRANSYS: A Franchize Inutribution Syztem Location Moudel."

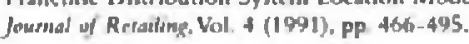

rate. Revenue allocation is based on the advertising dollars spent on the brand and the distance between each unit and the center of the zone. Once the revenues are allocated to the unirs in the demand zone, the model uses a maximizarion function based on three objectives: (1) maximizing system revenues, (2) maximizing new-unit revenues, and (3) maximizing existing-property sales. Constraints on the objective function may be set to maxinize system sales while keeping existing-property sales intact (i.e., a zero-impact scenario) Application of the FRANSYS model to the hospitality industry would require modification of data input to conform to the market and product characteristics of the hospitality industry, but few other modifications would be necessary. Exhibit 7 gives the steps involved in the development of a franchise-systemgrowth nodel.

We recommend that lodging firms reconsider theit current policy framework. which we believe emhodics a reactionary approach to impact assessment. We encourage analysts to use an assessment methodology that is research-based. rather than following from personal judgment as often occurs. Finally. we suggest an investigation of adapting the franchise-system-growth model for the lodging industry. The benufits of using such a model include improved relations with franchisees, better measurement of impact. and the maximization of system revenues. Growth models can aid franchisors in selecting sites that limit the impact on existing units and maxinize system revenue. Models in the family of the FRANSYS model are suitable for the hospitality franchisors, and franchisors may be wise to adopt a proactive approach for managing territorial conflicts with their franchisees to blunt the prospects of restrictive legislation.
Data from the franchisor and

ึำ comianies. such as

Smilh Travel Research, are

generatly more reliable than

dala from local managers. 